\title{
Correlation of factorial weights of separate motor coordination structure indicators, which characterize motor function level of different age groups' schoolchildren
}

\author{
Baginska O.V. \\ Chernigov National Pedagogical University named T. G. Shevchenko
}

\begin{abstract}
Purpose:

to find out correlation of the most significant indicators' factorial weights, which characterize motor coordination structure of different age groups' schoolchildren.

Material: $\quad$ in the research 901 schoolchildren of age from 6 to 15 years participated (466 boys and 435 girls). We used computer stabiloanalyzer with biological feedback.

Results: $\quad$ we the received factorial loads of separate indicators of motor coordination structure. Correlation of the weights showed change of their significance in the process of effective motor behavior's ensuring. We found body proportions changes' substantial influence on formation of compensatory mechanisms in sustaining body vertical position as well as the most important indicators of motor coordination structure, which have noticeable specific weight for all age groups.

Conclusions: the received data can be used for modeling the process of schoolchildren's motor function's development. Factorial weights and their correlations facilitate optimization of motor function's development methodic in the process of physical culture and sports' practicing.

Keywords: coordination, stabilography, balance, movements, factors, schoolchild
\end{abstract}

\section{Introduction}

The problem of physical education process's perfection in compliance with modern educational demands has been becoming more and more relevant. As on to day we can observe steady tendency to humanization of education, to its personality's orientation. It updates the question about consideration of individual and individual typological aspects of motor control for children's and adolescents' effective motor behavior. Development of coordination is of great significance in formation of motor function in the whole [11, 22]. It is known [6] that coordination is "control over excessive freedom of our motor organs and their transformation into fully controlled systems". Development of coordination abilities is realized in heterochronic way $[10,20,25]$. Some parameters of motor coordination substantially influence on formation of motor function in general [21, 26]. Consideration of age specifics in formation of motor control mechanisms in physical education and sport training processes will permit to optimize formation of human motor function in the whole [9, 10, 27]. It has been proved [17], that purposeful training methodic shall be based on understanding of laws of motor function and movements' formation and development in ontogeny. It was found [16] that vertical position regulation mechanisms ensure balance reliability in orthography stance and determine reliability of sportsmen's control over free movements. In the researches [8] it is noted that knowledge of aspects of vertical position firmness formation in ontogeny is a necessary condition for motor skills' perfection and harmonious development of children and adolescents. The purposefulness of coordination abilities' more profound study is stressed on in other work [23]. High information potential and objectiveness of motor function's assessment

(c) Baginska O.V., 2017

doi:10.15561/18189172.2017.0301 with the help of bio-mechanical methods were proved by different authors [2, 7, 13]. It is proved [19] that application of computer stabiloanalyzer with biological feedback "Stabilan-01" permits to study and objectively assess coordination abilities and coordination structure of a movement.

In other works mean values of some motor coordination structure indicators were found $[3,5]$ as well as correlation between them and effectiveness of motor behavior [4, 24]. However, in different age groups these dependences were different $[4,5]$. In other works there was proved the purposefulness of motor coordination structure's modeling as the base of motor function's formation's optimization [14, 15]. But in available literature we have not found models of motor functions' development with determination of their factorial weight for different age schoolchildren groups. Most of researches on this problem are devoted to sportsmen or students [7, $15,16]$. There are some data, received in researching primary school age children14]. Results of sportsmen's studies reflect the aspects of motor behavior control. But they are conditioned by specific of kind of sports and are not suitable for assessment of schoolchildren's motor function.

Hypothesis: it was assumed that some bio-mechanical indicators of motor coordination structure are of different significance in effectiveness of motor behavior control in different age groups. The study of factorial weights and their correlations in 6-15 yrs. schoolchildren can facilitate motor function's optimization in physical culture and sport practicing processes.

The purpose of the work is to determine the most significant motor coordination structure's indicators, which characterize 6-15 yrs schoolchildren's motor function level and find out factorial weights of each of them in every age group. 


\section{Material and methods}

Participants: in the research 901 schoolchildren of age from 6 to 15 years participated (primary school pupils: 176 girls and 146 boys; secondary school pupils: 200 girls and 270 boys and senior pupils: 59 girls and 50 boys).

Organization of the research: experiment was carried out in bio-mechanical laboratory. We used computer stabiloanalyzer with biological feedback "Stabilan-01" and software StabMed 2.08. The test with visual feedback was fulfilled. Standing on stabilograph platform, schoolchild shall fix marker in the center of target at big scale of picture. Marker's movements were regulated by free movement of pupil's body mass center (BMC).

Statistical analysis: we fulfilled factorial analysis. The data were accumulated in Microsoft Excel exported to data base of SPSS. We received ten-dimensional space of the tested group. The received data were taken for factorial analysis according to criterion of adequacy of Kaiser Meyer - Olkin $(\mathrm{KMO}=0.82)$ and Bartlett's criterion of sphericity $(\mathrm{p} \leq 0.05)$. We also used varimax method of $\mathrm{G}$. Kaiser - one of methods of factors' analytical processing, which permits to give a variable the highest weight within one factor. Varimax method is analysis of main components.

\section{Results}

In our previous research we found dependence between ability for effective control over motor behavior and separate indicators, which characterize motor coordination structure of different age groups' schoolchildren. We found correlations between effectiveness of motor control and stabilography indicators: $\mathrm{Q}(\mathrm{x})$ - mean square deviation of pressure center by $\mathrm{x}$ axis; $\mathrm{Q}(\mathrm{y})$ - mean square deviation of pressure center by y axis; $\mathrm{R}$ - mean total range of body pressure center's oscillations; $\mathrm{V}$ - mean amplitude value of pupil's BC movement; SV - velocity of static kinesiogram square's change; QBF - quality of balance function; NSV - normalized square of vector gram; STVV - percentage of velocity vector's sharp turns in respect to total quantity of vectors; MLV - mean linear velocity; AMV - mean angle velocity of direction changes of BC movement's velocity vectors $[4,5]$. But in different age groups these dependences were different [4]. It requires finding factorial weights of motor coordination structure.

The first collective factor, which characterizes the ability to keep static balance, has the maximal weight. It total contribution to general dispersion was: in girls' group - from $31.61 \%$ to $49.81 \%$; in boys' group - from $35.94 \%$ to $48.76 \%$ (depending on age group).

The first factor in all age groups includes such indicators as; Q(x); Q(y); R; V; SV; QBF; NSV; MLV. Their significance in different girls' age groups is shown in fig. 1; for boys - in fig. 2 .

The second factor included, mainly, the indicators, which characterize activity of keeping balance processes in all age groups. We found higher significance of this factor in boys and girls' groups in periods of active increase of body total sizes and change of body proportions. Its total contribution in general dispersion was from $15.35 \%$ to

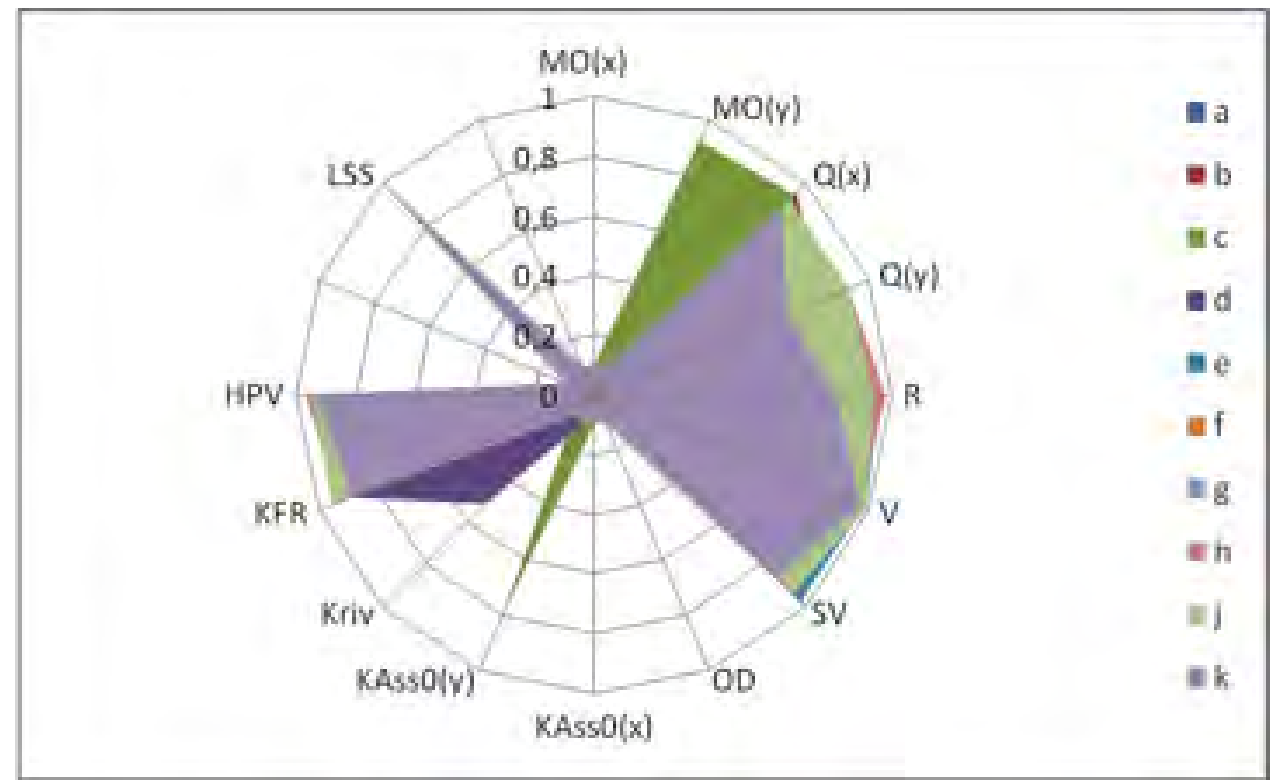

Fig.1. Correlations of significance of separate motor coordination structure's indictors, which were included in the first collective factor of different age groups' girls ( $a-6$ years; $b-7$ years; $c-8$ years; $d-9$ years; e -10 years; $f-11$ years; $\mathrm{g}-12$ years; $\mathrm{h}-13$ years; $\mathrm{j}-14$ years; $\mathrm{k}-15$ years). Indicators of motor coordination structure:

$\mathrm{MO}_{(\mathrm{y})}$ - mean sagittal shift; $\mathrm{MO}_{(\mathrm{x})}$ - mean frontal shift; $\mathrm{OD}$ - Assessment of movement; $\mathrm{Q}(\mathrm{x})$ - mean square deviation of pressure center by x axis; $Q(y)$ - mean square deviation of pressure center by y axis; $R$ - mean total range of body pressure center's oscillations; V - mean amplitude value of pupil's BC movement; SV - velocity of static kinesiogram square's change; QBF - quality of balance function; NSV - normalized square of vector gram; MLV - mean linear velocity; Kriy - mean coefficient of curvature; $\mathrm{KAssO}(\mathrm{x})$ - asymmetry coefficient in respect to $\mathrm{x}$-axis; $\mathrm{KAssO}(\mathrm{y})$ asymmetry coefficient in respect to $y$-axis. 
25.53\% depending on age group.

The third factor included indicators, which reflected shift of histogram in definite direction; asymmetry of BC deviation and individual aspects of BC deviation's compensation. Its total contribution to general dispersion was from $10.69 \%$ to $16.24 \%$.

The received factorial weights permitted to mark out the most significant indicators of motor coordination structure in every age group, as the base for modeling of motor function's training.

\section{Discussion}

The fulfilled study is a logical continuation of a number of other experimental researches on formation of school age children's motor function [3, 4, 5].

The experiment proved the data [8] about improvement of children's before 7 age yrs. posture regulation and improvement of central mechanisms of 9-10 yrs. children's motor regulation. We proved the work [16] about worsening of vertical position's regulation, in case of problems with it in 7 years children. In our research it reflected in reduction of first factor's specific weight and increase of the second

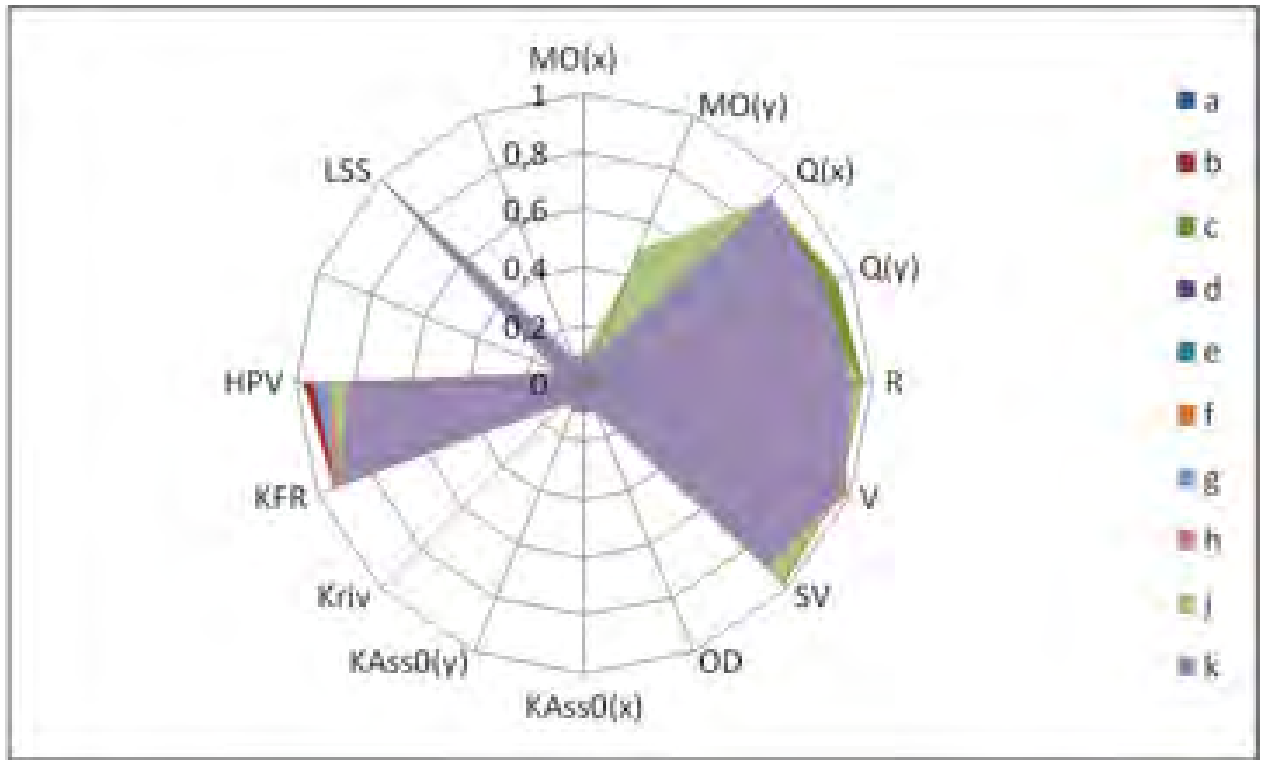

Fig.2. Correlations of significance of separate motor coordination structure's indictors, which were included in the first collective factor of different age groups' boys ( $a-6$ years; $b-7$ years; $c-8$ years; $d-9$ years; e -10 years; $f-11$ years; $\mathrm{g}-12$ years; $\mathrm{h}-13$ years; $\mathrm{j}-14$ years; $\mathrm{k}-15$ years). Indicators of motor coordination structure: $\mathrm{MO}_{(\mathrm{y})}$ - mean sagittal shift; $\mathrm{MO}_{(\mathrm{x})}$ - mean frontal shift; $\mathrm{OD}$ - Assessment of movement; $\mathrm{Q}(\mathrm{x})$ - mean square deviation of pressure center by x axis; $Q(y)$ - mean square deviation of pressure center by y axis; $R$ - mean total range of body pressure center's oscillations; V - mean amplitude value of pupil's BC movement; SV - velocity of static kinesiogram square's change; QBF - quality of balance function; NSV - normalized square of vector gram; MLV - mean linear velocity; Kriy - mean coefficient of curvature; $\mathrm{KAssO}(\mathrm{x})$ - asymmetry coefficient in respect to $\mathrm{x}$-axis; $\mathrm{KAss} \mathrm{O}(\mathrm{y})$ - asymmetry coefficient in respect to y-axis.

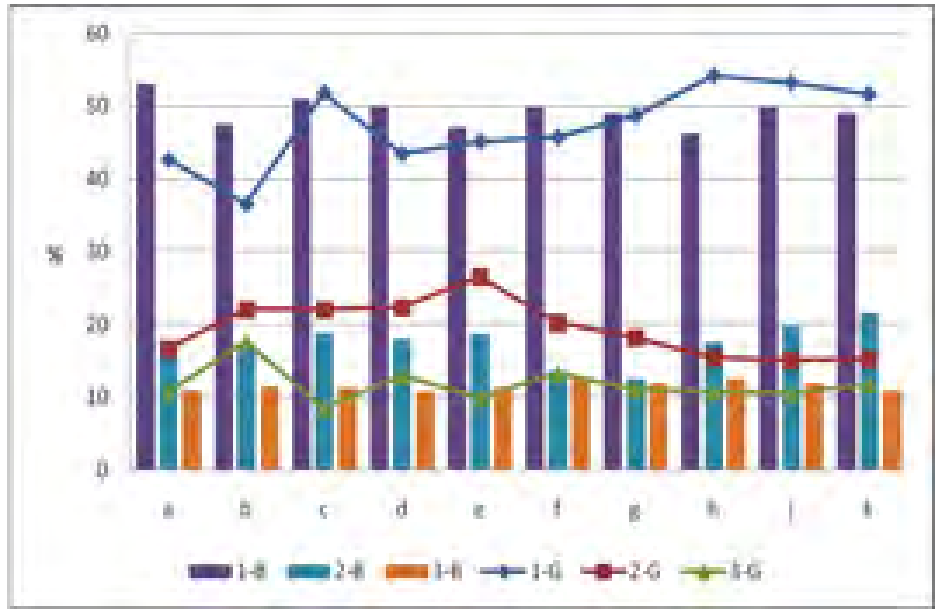

Fig. 3. Correlation of factorial weight of separate motor coordination structure's indicators, which characterize different age groups' schoolchildren's motor function: ( $a-6$ years; $b-7$ years; $c-8$ years; $d-9$ years; e -10 years; $f-11$ years; $g-12$ years; $h-13$ years; $j-14$ years; $k-15$ years; $1-G$ - first factor, girls; $2-G$ - second factor, girls; 3-G - 3 factor girls; 1-B - first factor, boys; 2-B - second factor, boys; 3-B - third factor, boys). 
factor's significance. It is a result of resilience's worsening and more effective task's fulfillment in active sustaining of body vertical position. It coincides with research [16] and is connected with dynamic of sensor systems' roles' changing in the process of 7-9 yrs. children's mastering movements. The received by us changes of schoolchildren's factorial structure in the period of puberty coincide with other results [12]. They are explained by morphological functional reconstructions of all systems of children's organisms. It is also confirmed by confident correlations between changes of motor coordination structure's main indicators and changes of body total sizes.

The received by us data prove the results of studies of primary school pupils' motor coordination structure [14], as well as secondary and senior school age children дітей $[12,15,18]$. However, determination of their significance in effectiveness of motor behavior control, correlation of factorial weights, permitted to substantially supplement other researches.
In contrast to other researches $[12,15]$ in the experiment children with average level of motor activity were involved. It permitted to use the obtained data for modeling the development of schoolchildren's motor function. Such models are suitable for application in comprehensive educational establishments for optimization of physical culture teaching methodic.

\section{Conclusions}

The received data about correlation of separate motor coordination structure indicators' factorial weight in children of $6-15$ yrs. age witness about change of their significance in ensuring of motor behavior effectiveness, depending on age group. They can be used for modeling of schoolchildren's motor function's development. They are components of organization of physical culture teaching in conditions of modern school.

\section{Conflict of interests}

The author declares that there is no conflict of interests.

\section{References:}

1. Anokhin PK. Ocherki po fiziologii funkcional'nykh sistem [Essays on physiology of functional systems], Moscow: Medicine; 1975. (in Russian)

2. Arkhipov OA. Biomekhanichni tekhnologii u fizichnij pidgotovci studentiv [Bio-mechanical technologies in students' physical training], Kiev: NPU; 2012. (in Ukrainian)

3. Baginska OV. Zdatnist' do utrimannia rivnovagi ditej molodshogo shkil'nogo viku iak pokaznik rozvitku ikh rukhovoi funkcii $\mathrm{v}$ proces navchannia fizichnoi kul'turi [Ability to keep balance in primary school pupils as indicator of their motor function's development in the process of physical culture practicing]. Naukovo-pedagogichni problemi fizichnoi kul 'turi, 2014;(44)14:53-56. (in Ukrainian)

4. Baginska OV. Modeliuvannia biodinamichnoi ta koordinacijnoi strukturi rukhu v procesi integral'noi ocinki rozvitku rukhovoi funkcii shkoliariv 6-15 rokiv [Modeling of motor bio-dynamic and coordination structure in integral assessment of 6-15 yrs. age schoolchildren's motor function]. Visnik Chernigivs'kogo nacional'nogo pedagogichnogo universitetu imeni T.G. Shevchenka, 2016;139(1):8 - 12. (in Ukrainian)

5. Baginska OV. Osoblivosti upravlinnia rukhami u shkoliariv riznikh vikovikh grup [Special aspects of motor control of different age groups schoolchildren]. Visnik Chernigivs'kogo nacional'nogo pedagogichnogo universitetu imeni T.G. Shevchenka, 2015;129(1):14-18. (in Ukrainian)

6. Bernshtejn AN. O lovkosti i ee razvitii [On dexterity and its training], Moscow: Physical Culture and Sport; 1991. (in Russian)

7. Garkusha SV. Biomekhanichnij kontrol' koordinacijnikh zdibnostej kvalifikovanikh sportsmenok, iaki specializuiut'sia v sportivnij borot'bi [Bio-mechanical control of qualified sportswomen's coordination, who specialize in sport wrestling]. Visnik Chernigivs'kogo nacional'nogo pedagogichnogo universitetu imeni T.G. Shevchenka, 2011;86:41-44. (in Ukrainian)

8. Gribanov AV, Pushkareva IN. Vozrastnye osobennosti izmeneniia ustojchivosti vertikal'noj pozy u mladshikh shkol'nikov [Age aspects of vertical position's stability changes in primary school pupils]. Mezhdunarodnaia konferenciia «Fiziologiia razvitiia cheloveka» [International conference "Physiology of human development], Moscow; 2004. P. 136 - 137. (in Russian)

9. Gurfinkel' BC, Koc IaM, Shik ML. Reguliaciia pozy cheloveka [Regulation of human position], Moscow: Science; 1965. (in Russian)

10.Dmitriev SV. Ontogenez psikhomotoriki i operacionnykh sistem «zhivykh dvizhenij» rebenka [Ontogeny of psychomotor processes and operational systems of child's "live movements"]. Fizicheskoe vospitanie studentov tvorcheskikh special'nostej, 2007;1:119-131. (in Russian)

11.Donskoj DD. Zakony dvizheniia $v$ sporte [Laws of moving in sports], Moscow: Physical Culture and Sport; 1968. (in Russian)

12.Kosenko IuV, Dmitrenko LM, Mendzherickij AM, Tregubenko OA. Sravnitel'nyj analiz stabilograficheskikh i sensomotornykh pokazatelej u zdorovykh shkol'nikov i detej s intellektual'noj nedostatochnost'iu v sootvetstvii s urovnem ikh dvigatel'noj aktivnosti [Comparative analysis of healthy children's stabilograph and sensor-motor indicators and children's with intellectual deficiency in compliance with their motor activity]. Sovremennye problemy nauki $i$ obrazovaniia, 2013;6:30-35. (in Russian)

13.Nosko MO, Arkhipov OA. Biometriia rukhovikh dij liudini [Bio-metering of human motor actions], Kiev: Word; 2011. (in Ukrainian)

14.Nosko MO, Nosko IuM. Biomekhanichne modeliuvannia rukhovikh iakostej shkoliariv pochatkovoi shkoli [Biomechanical modeling of primary school pupils' motor abilities]. Naukovo-pedagogichni problemi fizichnoi kul 'turi, 2013;5(30): 144-153. (in Ukrainian)

15.Pochtar OM. Model'ni kharakteristiki stabilografichnikh pokaznikiv statodinamichnoi rivnovagi gimnastokkhudozhnic' I rozriadu [Model characteristics of staticdynamic balance stabilograph indicators in calisthenic gymnasts of first sport category]. Visnik Chernigivs'kogo nacional'nogo pedagogichnogo universitetu imeni T.G. Shevchenka, 2011;91(2):224-226. (in Ukrainian)

16.Prijmakov OO. Strukturno-funkcional'na organizaciia vzaiemodii sistem organizmu pri reguliuvanni pozi i rukhu liudini. Dokt. Diss. [Structural-functional organization of 
organism's systems interaction in regulation human position and moving. Doct. Diss.], Kiev; 1995. (in Ukrainian)

17.Rovnij AS. Sensorni mekhanizmi upravlinnia tochnisnimi rukhami liudini [Sensor mechanisms of control over fine human movements], Kharkiv; KSIPC: 2001. 995. (in Ukrainian)

18.Samonenko SB. The dynamics of the focal qualities in girls aged 10-15 years. Pedagogics, psychology, medicalbiological problems of physical training and sports, 2015; 19(3): 52-57. doi:10.15561/18189172.2015.0308

19.Sliva SS, Sliva AS, Krivec DV. Stabiloanalizator «Stabilan-01» v sporte [Stabiloanalyzer "Stabilan-01" in sports]. Medicinskie informacionnye sistemy, 2004;6:25-29. (in Russian)

20.Farfel' VS. Upravlenie dvizheniiami $v$ sporte [Motor control in sports]. Moscow: Physical Culture and Sport; 1975. (in Russian)

21.Boraczynski T, Zaporozhanov VA. Motor learning as a criterion for evaluating coordination motor abilities. Pedagogics, psychology, medical-biological problems of physical training and sports, 2011;10:110-117.

22.Zaporozhanov VA, Boraczynski T. Preparation of children with the limited possibilities to tutoring in a comprehensive school - a step to spirituality and humanism. Pedagogics, psychology, medical-biological problems of physical training and sports, 2009;4:52-55.

23.Kolumbet AN. Theoretical and methodical going near development of coordinating capabilities of young people. Pedagogics, psychology, medical-biological problems of physical training and sports, 2012;4:62-65.

24.Ivashchenko OV. Modeliuvannia procesu fizichnogo vikhovannia shkoliariv [Modeling of schoolchildren's physical education process]. Kharkiv: OVS; 2016. (in Ukrainian)

25. Olsson B, Kirchengast S. The leading hand in bimanual activities - A search for more valid handedness items. Anthropologischer Anzeiger. 2016;73(4):323-33.

26.Trinies V, Chard AN, Mateo T, Freeman MC. Effects of Water Provision and Hydration on Cognitive Function among Primary-School Pupils in Zambia: A Randomized Trial. Plos One. 2016;11(3).

27.Truszczynska A, Drzal-Grabiec J, Snela S, Rachwal M. Postural stability of children undergoing training in karate. Archives of Budo. 2015;11: 53-60.

\section{Information about the author:}

Baginska O.V.; http://orcid.org/0000-0002-2856-8701; olga-baginskaya@yandex.ua; Chernigov National Pedagogical University named T. G. Shevchenko; Hetman Polubotka str., 53., Chernihiv, 14013, Ukraine.

Cite this article as: Baginska OV. Correlation of factorial weights of separate motor coordination structure indicators, which characterize motor function level of different age groups' schoolchildren. Pedagogics, psychology, medical-biological problems of physical training and sports, 2017;21(3):100-104. doi:10.15561/18189172.2017.0301

The electronic version of this article is the complete one and can be found online at: http://www.sportpedagogy.org.ua/index.php/PPS/issue/archive

This is an Open Access article distributed under the terms of the Creative Commons Attribution License, which permits unrestricted use, distribution, and reproduction in any medium, provided the original work is properly cited (http://creativecommons.org/licenses/by/4.0/deed.en).

Received: 11.02 .2017

Accepted: 25.02.2017; Published: 30.04.2017 